\title{
Rapid flow-injection sandwich-type immunoassays of proteins using an immobilized antibody reactor and adenosine deaminase-antibody conjugates
}

\author{
I.H. LEE and M E. MEYERHOFF * \\ Department of Chemistry, University of Michigan, Ann Arbor, MI 48109-1055 (U.S.A)
}

(Recerved 12th April 1989)

SUMMARY

\begin{abstract}
A rapıd flow-injection sandwich enzyme immunoassay suitable for the direct determination of proteins in biological samples is described. The proposed system utilizes h̆ighly active adenosine deaminase-antıbody conjugates in conjunction with a flow-through immunoreactor and an ammonum ion-selective potentiometric detector. After appropnate sample/reagent injection steps, the enzyme activity bound to the reactor is measured by diverting a continuously flowing stream of substrate (adenosine) through the packed immunocolumn and detectıng liberated ammonium ions downstream with a tubular ammonium ion-selective electrode. The bound enzyme activity is directly proportional to the concentration of analyte in the onginal sample. By using non-equilibrium flow-rates of sample and reagent slugs, a single protein assay takes less than 12 min, including regeneration of the reactor. The proposed method is shown to be selective, reproducible and capable of determining accurately the model proteın (human IgG) at sub- $\mu \mathrm{g} \mathrm{ml}{ }^{1}$ concentrations.
\end{abstract}

In recent years, newer enzyme immunoassay (EIA) methods have essentially replaced classical radioimmunoassay (RIA) procedures for the determination of a wide variety of biomolecules at trace levels [1-4]. Although many lower molecular weight species (e.g., drugs and hormones) can be determined using rapid homogeneous EIA techniques (e.g., EMIT assay), the selective determination of proteins generally requires the use of much slower heterogeneous (i.e., solid-phase) approaches (e.g., ELISAs). Prolonged equilibration periods coupled with multiple pipetting and washing steps make it difficult to automate fully such solid-phase methods. A potentially more rapid approach would involve the use of reusable immunoreactors in flow-through arrangements. Such a concept was recently reported by de Alwis and Wilson $[5,6]$ for both sandwich- and competitivetype assays using glucose oxidase as the labeling enzyme and amperometric detection of liberated peroxide. In this work, this general concept was further investigated by developing a flow-injection sandwich immunoassay system that employs adenosine deaminase as the tracer together with simple flow-through potentiometric detection of the product of the enzymatic reaction (ammonium).

As illustrated in Fig. 1, the proposed flow-injection assay method is based on the sequential sandwich immunoassay technique. After sequential injections of analyte and enzyme-antibody conjugate (via valve 2) (see Fig. 2), unbound species (analyte and conjugate) are washed away from the reactor by the flow-injection carrier buffer. After a suitable washing period, a continuously flowing stream of substrate is diverted through the reactor (via valve 1). The amount of bound activity, as measured via a downstream 

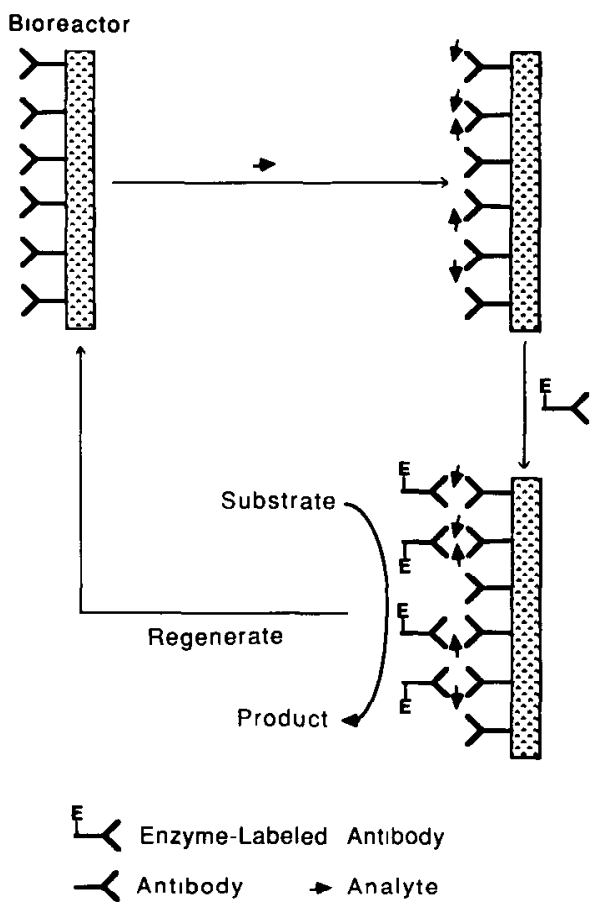

Fig. 1. Schematic diagram illustratıng the principles of the enzyme-lınked flow-injection sandwich immunoassay system.

detector, is directly proportional to the concentration of analyte present in the sample. After detecting bound enzyme activity, the immunoreactor can be regenerated by washing with a low-pH buffer (via valve 3 ).

In the assay described here, highly active adenosine deaminase (ADA) was utilized as the labeling enzyme and both human IgG (HIgG) and $\alpha_{1}$-acid glycoprotein were chosen as the model protein analytes. Ammonium ions generated from the enzymatic reaction are detected with a simple

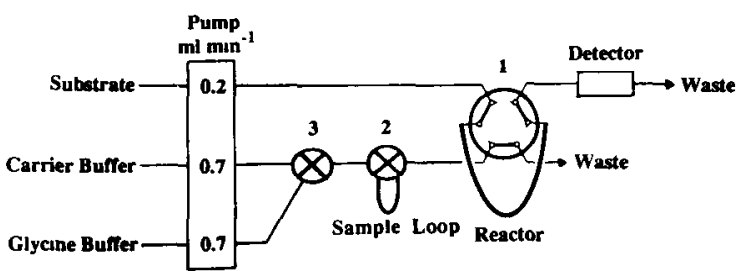

Fig. 2. Schematıc diagram of the flows and valving arrangement used for the flow-injection immunoassay system. and sensitive tubular ammonium ion-selective electrode. The major advantage of the proposed system is an improvement in assay speed. This is achieved by adapting non-equilibrium flow-rates to deliver the sample and reagent solutions. In addition, as in previous flow-injection immunoassay methods $[5,6]$, the proposed system does not require separate washıng steps since all unbound species and interferences are washed continuously by the stream of flow-injection carrier buffer. It will be shown that the final assay method is selective, reproducible and sensitive enough to detect sub- $\mu \mathrm{g} \mathrm{ml}^{-1}$ concentrations of proteins.

\section{EXPERIMENTAL}

\section{Apparatus}

A schematic diagram of the complete flow-injection immunoassay system is shown in Fig. 2. A Rainin Rabbit peristaltic pump was used to deliver the sample, conjugate and carrier buffer streams through the system. A Rheodyne Model 7125 four-way valve, equipped with a $300-\mu 1$ sample loop, was employed to introduce samples and conjugates to the immunoreactor (valve 2). The immunoreactor was constructed from a Rheodyne four-way rotary Teflon valve (valve 1) by replacing the normal sample loop with a piece of silicone-rubber tubing filled with antibody-immobilized solid-phase particles. Connections were made by using short sections of tight-fittıng siliconerubber tubing.

Potentiometric measurements of ammonium ions liberated from the ADA-catalyzed reaction were made using a tubular flow-through ammonium ion-selective and reference electrode arrangement similar in design to those described previously [7-9]. The potentiometric signals were measured with an Altex SelectIon $2000 \mathrm{pH} / \mathrm{mV}$ meter and recorded on a Linear Model 1201 strip-chart recorder.

A Perkin-Elmer Lambda Array 3840 photodiode array UV-VIS spectrophotometer operated by a Model 7300 Professional Computer was used to record the UV-VIS spectra of enzymes, human IgG, $\alpha_{1}$-acid glycoprotein and antibody-enzyme conjugates. 


\section{Reagents}

The following materials were obtained from Sigma (St. Louis, MO): human IgG, $\alpha_{1}$-acid-glycoprotein, adenosine deaminase (ADA) (E.C. 3.5.4.4) type VI, horseradish peroxidase (HRP) (E.C. 1.11.1.7) type IV, adenosine, goat anti-HIgG serum, rabbit anti-human $\alpha_{1}$-acid glycoprotein, goat anti-HIgG-urease conjugate, goat antiHIgG-alkaline phosphatase and bovine serum albumin (BSA) (fraction V). Porcine pepsin (E.C. 3.4.23.1) was a product of Boehringer Mannheim Biochemicals (Indianapolis, IN) and SeraChem Clinical Chemistry Control Serum (Human) Level 1-Assayed and silicone-rubber tubings were obtained from Fisher Scientific (Detroit, MI). NOR-Partigen RID (radial immunodiffusion) plates and $\mathrm{HIgG}$ standards were from Calbiochem (San Diego, CA). Carbonyldiimidazole (CDI)activated glycerol-coated controlled-pore glass (CPG) beads (250 $\AA$ pore size, 120-200 mesh) were purchased from Pierce Chemicals (Rockford, IL) and Sephadex G-25 and G-200 from Pharmacia Fine Chemicals (Uppsala, Sweden).

All other chemicals were of analytical-reagent grade. Standard solutions and various buffers were prepared with deionized water. The assay buffer for $\mathrm{HIgG}$ and $\alpha_{1}$-acid glycoprotein was $0.05 \mathrm{M}$ tris(hydroxyamino)methane-hydrochloric acid (Tris-HCl), $\mathrm{pH}$ 7.5. Dilutions of goat anti$\mathrm{HIgG}-\mathrm{ADA}$ conjugates, rabbit and anti- $\alpha_{1}$-acid glycoprotein-ADA and protein standards (HIgG and $\alpha_{1}$-acid glycoprotein) were made using this assay buffer containing $0.1 \mathrm{M} \mathrm{NaCl}, 5.0 \%(\mathrm{w} / \mathrm{v})$ BSA, 0.5\% (v/v) Tween-20 and 0.01\% (w/v) $\mathrm{NaN}_{3}$ (dilution buffer). The carrier stream buffer was $0.025 \mathrm{M}$ Tris- $\mathrm{HCl}, \mathrm{pH} 7.5$ and the bound ADA activity was measured by passing $0.25 \mathrm{mM}$ adenosine (in assay buffer) through the immunoreactor. The immunoreactor was regenerated by washing with $0.1 \mathrm{M}$ glycine- $\mathrm{HCl}, \mathrm{pH} 2.2$.

\section{Affinity purification of IgG antibodies}

The commercial antibodies were affinity purified before immobilization on CPG. Goat antiHIgG (106 mg) or rabbit anti-human $\alpha_{1}$-acid glycoprotein $(54 \mathrm{mg}$ ) antisera were applied to columns of CPG-HIgG or CPG- $\alpha_{1}$-acid glycoprotein, respectively. The affinity supports for these col- umns were prepared by immobilizing $\mathrm{HIgG}$ and $\alpha_{1}$-acid glycoprotein on CDI-activated CPG beads using the procedure outlined below for the preparation of the immuno-CPG beads. After washing the columns with PBS buffer, the bound antibodies were eluted with $700 \mathrm{ml}$ of $0.1 \mathrm{M}$ glycine buffer, $\mathrm{pH}$ 2.5. The eluted antibodies were immediately neutralized with $100 \mathrm{ml}$ of $2.0 \mathrm{M}$ Tris- $\mathrm{HCl}$ buffer, $\mathrm{pH}$ 8.0. These solutions were then dialyzed against PBS buffer overnight at $4^{\circ} \mathrm{C}$. With anti-HIgG, the final concentration (5-6 $\mathrm{mg} \mathrm{m} \mathrm{m}^{-1}$ ) of the antibody was determined by absorbance measurement at $280 \mathrm{~nm}$ using a value of $A_{280 \mathrm{~nm}}^{1 \%}=15$ [10].

\section{Preparation of goat antl-HIgG F(ab') 2}

The $\mathrm{F}\left(a b^{\prime}\right) 2$ fragment of goat anti-HIgG was prepared by digesting the antibody with pepsin as described elsewhere [11]. Briefly, goat anti-HIgG (106 mg) was dissolved in $0.01 \mathrm{M}$ phosphate buffer and dialyzed against $0.1 \mathrm{M}$ acetate buffer, $\mathrm{pH} 4.5$, overnight at $4^{\circ} \mathrm{C}$. Pepsin was then added to this antibody solution at a final pepsin to protein ratio of $1: 100$ and the reaction mixture was incubated for $16 \mathrm{~h}$ at $37^{\circ} \mathrm{C}$. The digest reaction was terminated by dialyzing the mixture against $0.1 \mathrm{M}$ phosphate buffer, $\mathrm{pH} 7.0$, for $24 \mathrm{~h}$. The resulting solution was then affinity purified by using the HIgG-CPG column as described above. The final concentration of $F\left(a b^{\prime}\right) 2\left(2.9 \mathrm{mg} \mathrm{ml}^{-1}\right)$ was determined by absorbance measurement at $280 \mathrm{~nm}$ using a value of $A_{280 \mathrm{~nm}}^{1 \%}=14.8$ [12].

\section{Preparation of antibody-CPG beads}

The affinity purified antibodies or $\mathrm{F}\left(\mathrm{ab}^{\prime}\right) 2$ fragments were immobilized onto CDI-activated CPG beads as described previously [13,14]. The CDIactivated beads $(200 \mathrm{mg})$ were suspended in 800 $\mathrm{ml}$ of $0.1 \mathrm{M}$ sodium borate buffer, pH 8.5, containing $200 \mathrm{ml}(3 \mathrm{mg})$ of the affinity-purified antibody. This suspension was first degassed with ultrasonic vibration for $5 \mathrm{~min}$, and then was slowly shaken for 2 days at $4^{\circ} \mathrm{C}$. The coupled yield of the protein ( $2.6 \mathrm{mg}$ protein per $200 \mathrm{mg}$ CPG) was determined by measuring the absorbance at 280 $\mathrm{nm}$ of the supernatant before and after the coupling reaction [12]. Based on the amount of imidazole originally present on the CPG beads (ca. 
$50 \mu \mathrm{mol} \mathrm{g}^{-1}$ solid), and the low molar absorptivity of imidazole at $280 \mathrm{~nm}\left(4.31 \mathrm{~mol}^{-1} \mathrm{~cm}^{-1}\right)$, measurements of the protein content in the supernatant (after appropriate dilution) are not affected significantly $(<1 \%)$ by the imidazole liberated via the coupling reaction. The resulting immuno-beads were stored at $4^{\circ} \mathrm{C}$ in $0.05 \mathrm{M}$ phosphate buffer, $\mathrm{pH} 7.0$, containing $0.01 \%(\mathrm{w} / \mathrm{v}) \mathrm{NaN}_{3}$ until use.

\section{Preparation of immunoreactors}

The antibody-CPG beads (ca. $22 \mathrm{mg}$, dry weight) were slurried in an assay buffer and packed into a silicone-rubber tube $(2.5 \mathrm{~cm} \times 1.54 \mathrm{~mm}$ i.d.). A thin plug of Teflon wool was placed at both ends of the reactors to prevent the antibody-CPG beads from leaking and moving with the flowing carrier stream. The antibody reactors were then washed several times with assay buffer and $0.1 \mathrm{M}$ glycine buffer, $\mathrm{pH} \mathrm{2.2,} \mathrm{to} \mathrm{remove}$ any non-covalently bound antibody. Between experiments, the reactors were stored at $4{ }^{\circ} \mathrm{C}$ filled with assay buffer containing $0.01 \%(\mathrm{w} / \mathrm{v}) \mathrm{NaN}_{3}$.

Preparation of goat-ant $-H \operatorname{Ig} G-A D A$ and rabbit antl- $\alpha_{1}$-acid glycoprotein- $A D A$ conjugates

ADA was cross-linked to antibodies by a glutaraldehyde reaction [15]. The conjugate was prepared by adding $10 \mathrm{ml}$ of $2.5 \%$ glutaraldehyde

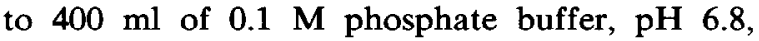
containing $0.65 \mathrm{mg}$ of antibody and 114 i.u. of ADA (187 i.u. $\mathrm{mg}^{-1}$ ) and by gently stirring the mixture for $2 \mathrm{~h}$ at room temperature. The resulting conjugates were then dialyzed against $0.05 \mathrm{M}$ phosphate buffer, $\mathrm{pH} 7.5$, overnight at $4^{\circ} \mathrm{C}$ to remove excess of glutaraldehyde. These conjugates were further purified by using a gel filtration column (Sephadex G-200, $50 \times 1.0 \mathrm{~cm}$ i.d.) equilibrated with the same buffer used to remove unreacted ADA. The ADA content of each effluent fraction (1.5-ml portion) was determined by measuring enzymatic activity [16] and the protein content by measuring the absorbance at $280 \mathrm{~nm}$. The first-eluted protein peak contained the desired ADA-antibody conjugate.

Flow-injection immunoassays for human $\operatorname{IgG}$ and $\alpha_{I}$-acid glycoprotein

As illustrated in Fig. 2, the streams of the carrier, substrate and regeneration buffer through the system were controlled by three rotary injection valves. For each assay cycle, samples containing $\mathrm{HIgG}$ or $\boldsymbol{\alpha}_{1}$-acid glycoprotein were introduced to the reactor via injection valve 2 and were carried through the immunoreactor with the carrier buffer. Following a brief wash period $(3 \mathrm{~min})$, the same injection valve was used to deliver a fixed amount of enzyme-labeled antibody to the reactor. During injection of the analyte and conjugate, valve 1 was switched to the "load" position (dashed line). This enabled the carrier buffer to wash all unbound species from the reactor (to waste), and the stream of substrate solution (adenosine in assay buffer) to flow through valve 1 to the detector. After loading the analyte and conjugate, the enzyme activity bound to the reactor was rapidly determined by turning valve 1 , thereby diverting the stream of substrate through the packed immunocolumn (solid line) and detecting the product of the enzymatic reaction downstream with the ammonium ion-selective electrode. Finally, the immunoreactor was regenerated by rotating valves 3 and 1 to divert a low-pH regeneration buffer through the immunocolumn for 2 min. After brief washing with assay buffer, the immunoreactor was ready for another assay cycle.

Dose-response curves were prepared by plotting observed potentials $(\Delta \mathrm{mV}$ ) (from the baseline potential of flowing adenosine-assay buffer solution) vs. HIgG or $\alpha_{1}$-acid glycoprotein concentrations in the standards. In some cases the background signal resulting from non-specifically adsorbed enzyme-antibody conjugate (at zero concentration of analyte protein) was first subtracted from the observed potential changes, yielding a "net" $\Delta \mathrm{mV}$ signal for the ordinate.

\section{Preparation of standard and sample solutions}

For stock standard solutions, HIgG (5 mg) and $\alpha_{1}$-acid-glycoprotein $(5 \mathrm{mg}$ ) were dissolved in 100 $\mathrm{ml}$ of $0.1 \mathrm{M}$ phosphate buffer, $\mathrm{pH} 7.2$, containing $0.05 \%$ BSA and stored at $-20^{\circ} \mathrm{C}$. Standard solutions of both $\mathrm{HIgG}$ and $\alpha_{1}$-acid-glycoprotein were prepared by diluting the above stock solutions with dilution buffer containing BSA and Tween-20. These working standards were freshly prepared for each calibration graph. SeraChem Human 
Control Serum (from Fisher Scientific) was used as a test sample for HIgG determinations. This serum sample was diluted at least 10000 -fold before injection into the immunoreactor and the unknown concentrations were determined graphically from the calibration graph.

\section{RESULTS AND DISCUSSION}

The analytical performance of the proposed system depends heavily on the characteristics of the immobilized antıbody reactor (e.g., stability and binding ability of immobilized antibodies, degree of non-specific adsorption). Physically adsorbed antibodies, although widely used, have limited long-term stability owing to significant desorption during continuous usage $[17,18]$. In this study, antibodies were covalently immobilized on CDI-activated glycerol-coated CPG beads and packed into a small reactor. The hydrophilic character of the glycerol coating, coupled with the uncharged nature of the carbamate linkage, minimizes the non-specific adsorption problems of the resulting immunosorbents (free from ion-exchange effects) $[19,20]$. The immobilized antibody CPG beads prepared in this study were stored for several months at $4^{\circ} \mathrm{C}$ without a significant decrease in antigen-binding ability.

The major advantage of using a flow-through reactor packed with immobilized antibody CPG beads over a tubular reactor (i.e., antibodies immobilized on the inner walls of a tubing) or a conventional stationary incubation device (e.g., test-tubes, plates, wells) is the efficient on-line mixing of the reagent stream while flowing through the beads. This effectively minimizes reagent diffusion barriers, and thus increases the rate of mass transfer between the analytes/reagents and immunosorbents. Further, the mechanical strength of CPG beads enables the assay system to employ high flow-rates, which can also help decrease assay times. The high protein loading capacity of the CPG beads used here [20] is also important. Indeed, the ideal immunoreactor should be small in size, yet should have a sufficient number of immobilized antibody binding sites to withstand the small decrease in immuno-binding activity that may occur during the repeated washing and regeneration steps. Under the assay conditions used in this work, CPG immunoreactors prepared by the methods outlined under Experimental could be used for at least 300 assay cycles (with pure standards) without more than a $10 \%$ decrease in the observed signal for a given dose of analyte proteın. Naturally, to account for even slight changes in the binding properties of the reactor and changes in the flow-rate of the reagent streams (due to tube stretching in the pump, etc.) dose-response calibrations should be prepared on a daily basis to achieve the highest degree of accuracy.

The detection capability of the proposed system is also highly dependent on the choice of the enzyme label. Ideally, labeling enzyme should have a high specific activity and low non-specific adsorption characteristics and should be stable upon chemical modification. In preliminary studies, urease, HRP, ADA and alkaline phosphatase were examined as labeling enzymes. Bound HRP and alkaline phosphatase activities were detected with a flow-through spectrophotometer as described previously [9] and ammonium ions liberated from bound urease were detected via the same flowthrough ammonium electrode system utilized to determine bound ADA activity. Of these enzymes, ADA appeared to satisfy the above requirements, particularly with regard to the lowest degree of the non-specific adsorption, and therefore yielded the best detection limits for the proposed flow-injection system. For example, Fig. 3 compares the dose-response curves for HIgG obtained by using urease-goat anti-HIgG antibody and ADA-goat anti-HIgG antibody conjugates, respectively. As can be seen, the ADA conjugate exhibited better detection limits. This is mainly due to the considerably lower non-specific adsorption properties of ADA toward the immunosorbent. It should be noted that the degree of non-specific adsorption for each enzyme label may be determined by injecting the appropriate $\mathrm{Ab}$-enzyme conjugate through the immunoreactor without prior injection of analyte protein. Absolute signal changes generated in this manner are directly proportional to the non-specific adsorption. Thus, increases in non-specific adsorption yield decreases in "net" signal changes for a given concentration of analyte 


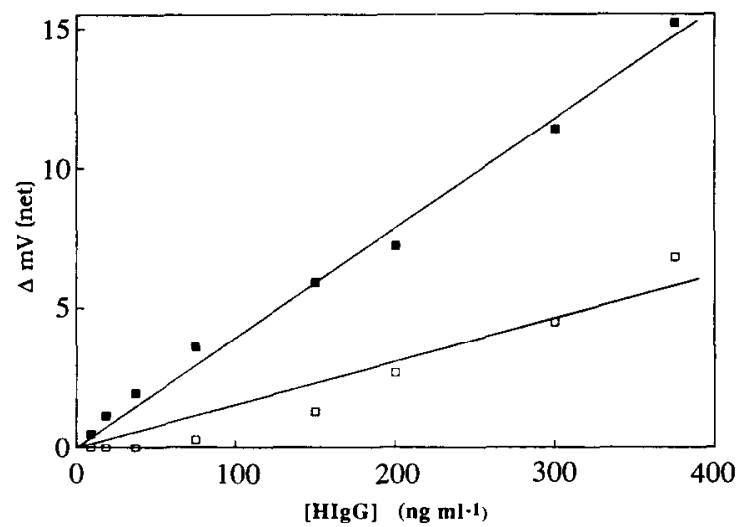

Fig. 3. Comparison of HIgG assay calıbration graphs usıng (ש) ADA-goat ant1-HIgG and () urease-goat ant1-HIgG conjugates.

protein (i.e., higher background signal). In general, the degree of non-specific adsorption of the $\mathrm{Ab}$-enzyme conjugates within the immunoreactors correlated with the concentration of conjugate in the injected volume. Consequently, to reduce the background in the final ADA-based system without a concomitant reduction in the signal resulting from specifically bound conjugate, a large injection volume of $300 \mu \mathrm{l}$ was employed.

Initially, several different ADA-rabbit anti- $\alpha_{1}$ acid glycoprotein and ADA-goat anti-HIgG conjugates were prepared in order to optimize the coupling reaction conditions. Such studies included varying the concentrations of ADA and/or glutaraldehyde used while maintaining a fixed concentration of antibody $\left(2.72 \mathrm{mg} \mathrm{ml}^{-1}\right)$ in the coupling reaction. However, both ADA and antibody precipitated when the amount of glutaraldehyde in the reaction mixture was greater than $0.2 \%(w / v)$. Conjugates prepared by using 1.54 $\mathrm{mg} \mathrm{ml} \mathrm{m}^{-1} \mathrm{ADA}$ and $0.06 \%$ glutaraldehyde retained the greatest percentage of the original ADA activity after the coupling reaction, and were therefore used in all subsequent experiments.

The catalytic activity of ADA conjugates bound to the immunoreactor was determined by detecting ammonium ions generated from adenosine downstream with an ammonium ion-selective electrode. The ammonium ion concentrations generated from ADA conjugates bound to the immunoreactors were typically lower than $1 \times$
$10^{-6} \mathrm{M}$. In this lower concentration region, the potentiometric response of the electrode exhibits a linear relationship with the ammonium ion concentrations. Therefore, all the standard protein dose-response curves were constructed by plotting net potential changes $(\Delta \mathrm{mV})$ vs. analyte concentrations, not log (analyte concentrations).

To optimize the proposed flow-injection immunoassay system, the effects of varying the flow-rates of the substrate, conjugate and analyte (HIgG) streams on the output signal were studied. For this, the absolute potential responses $(\mathrm{mV})$ of the electrode (detector) toward ammonium ions produced by the enzymatic reaction were determined at different flow-rates of the carrier stream (while maintaining the other two flow-rates constant). As shown in Fig. 4, the amount of reaction product increased as either the substrate or the conjugate flow-rate decreased. This result indicates that under the flow conditions studied, the association reaction between the conjugate and bound protein analytes does not reach equilibrium while the extent of enzyme reaction is directly related to the residence time of the substrate in the reactor (i.e., a nearly linear dependence). On the other hand, decreasing the analyte flow-rate resulted in only a slight increase in the response signal (see Fig. 4). This is mainly due to the presence of an excess of immobilized antibody in the reactor compared with the concentration of injected analyte. In addition, it is likely that the association binding rate of the analyte protein is

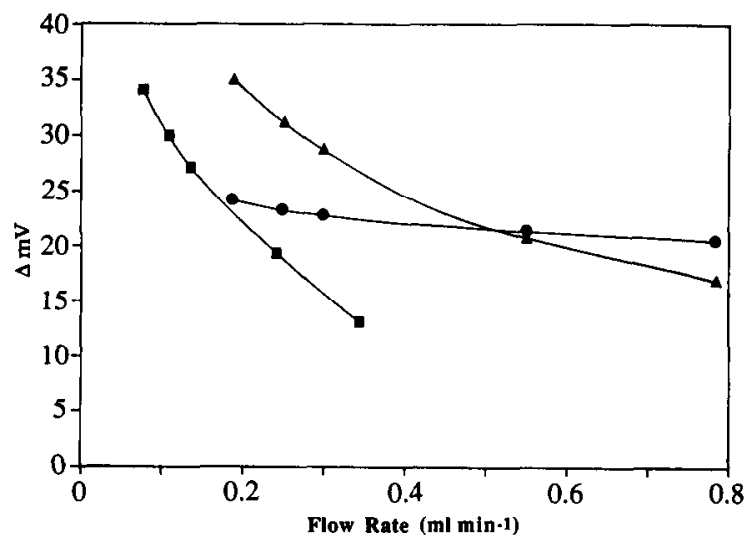

Fig. 4. Effect of (๑) analyte, (D) substrate and (A) conjugate flow-rates on the response signal for $\mathrm{HIgG}$ assay system. 


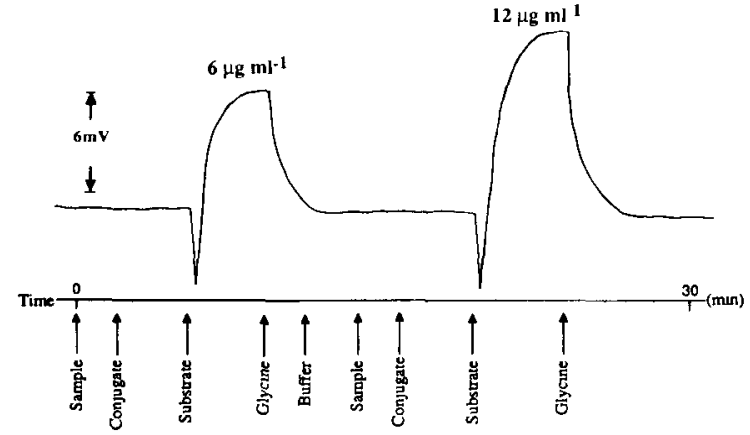

Fig 5. Typical strip-chart recording showing the reaction cycle and resulting output for the measurement of $\alpha_{1}$-acid glycoprotein with the flow-injection sandwich immunoassay system.

faster than that of the bulkier enzyme-antibody conjugate. Thus, even with a high flow-rate (e.g., $0.7 \mathrm{ml} \mathrm{min}^{-1}$ ), the injected analyte can react nearly completely with the immobilized antibody during the short period (ca. $40 \mathrm{~s}$ ) that the sample slug spends in the reactor. Based on these kinetic experiments, the substrate flow-rate was chosen to be $0.2 \mathrm{ml} \mathrm{min}-1$ and the flow-rate of injected sample and conjugate was fixed at $0.7 \mathrm{ml} \mathrm{min}$ min $^{-1}$ for all subsequent measurements.

Figure 5 illustrates a typical strip-chart recording showing the timing sequence and the resulting potentiometric output under the conditions outlined above for the flow-injection assay of $\alpha_{1}$-acid glycoprotein. The negative potential spikes in the trace occur because a small segment of residual carrier stream buffer $(0.025 \mathrm{M}$ Tris- $\mathrm{HCl}, \mathrm{pH} 7.5)$ contained within the immunoreactor passes through the detector when valve 1 is turned to divert the flowing adenosine solution through the reactor. This small segment of buffer is more dilute than the assay buffer used to prepare the adenosine solution (see Experimental). In addition, it contains a much lower background level of ammonium ions, since trace levels of ammonium are in fact present in the adenosine reagent used to prepare the substrate solution. As shown in Fig. 5, an entire assay cycle takes about $12 \mathrm{~min}$, including regeneration of the reactor.

A typical standard dose-response curve for the $\alpha_{1}$-acid glycoprotein assay is shown in Fig. 6. The working range is $3-15 \mathrm{mg} \mathrm{m}^{-1}$. The optimum concentration of conjugate used to obtain this

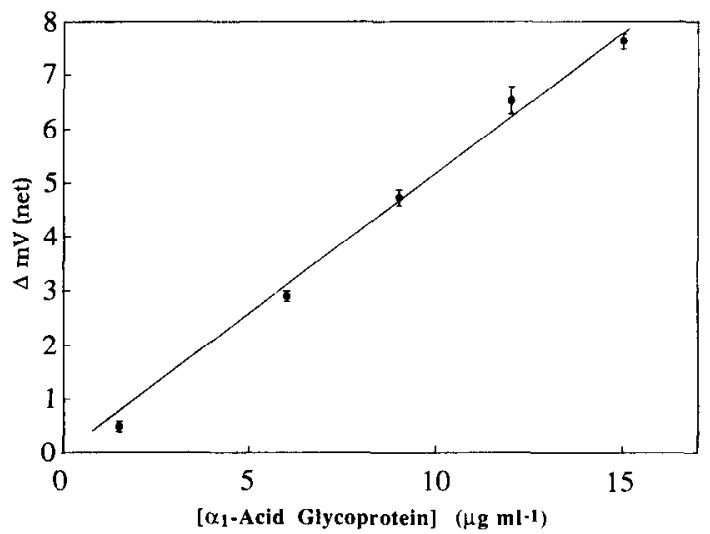

F1g. 6. Typical dose-response curve for detection of $\alpha_{1}$-acid glycoprotein using the non-equilibrium immunoassay (error bars show s.d. for $n=3$ ).

calibration graph was determined first by fixing the concentration of $\alpha_{1}$-acid glycoprotein and varying the concentration of conjugate. The resulting ratio of the specific enzyme-antibody conjugate binding to the non-specific binding was assessed. In most instances, a 1:400 dilution of the stock conjugate solution yielded a relatively high specific to non-specific binding ratio and was used to obtain the calibration graphs.

In the HIgG assay, a comparison was made between using immobilized whole antibody and $\mathrm{F}\left(a b^{\prime}\right) 2$ immunoreactors. As shown in Fig. 7, there is relatively little difference in the calibration graphs observed for both types of immunoreactors. In either case, the HIgG working range of the

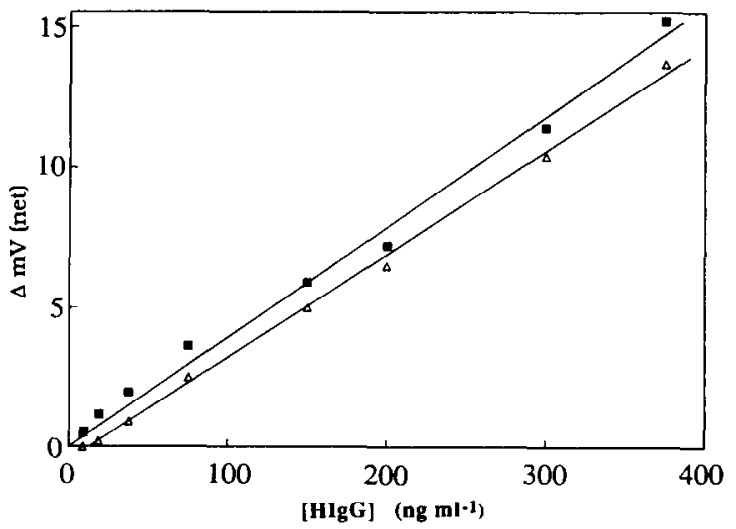

Fig. 7. Companson of $\mathrm{HIgG}$ calibration graphs using $F\left(a b^{\prime}\right) 2$ reactor and $(\Delta)$ whole anti-IgG reactor. 
TABLE 1

Comparison of results for the determınation of $\mathrm{HIgG}$ in a commercial control serum ${ }^{\text {a }}$

\begin{tabular}{llcl}
\hline Method & Value $\left(\mathrm{g} \mathrm{l}^{-1}\right)^{\mathrm{b}}$ & Method & ${\text { Value }\left(\mathrm{g} \mathrm{I}^{-1}\right)^{\mathrm{b}}}$ \\
\hline Ames OPTIMATE & $960 \pm 1.92$ & IL, MONACH. & $956 \pm 1.50$ \\
Beckman ICS & $8.62 \pm 175$ & Nephelometry & $8.49 \pm 135$ \\
DuPont ACA & $813 \pm 1.32^{\mathrm{c}}$ & Turbidimetry & $952 \pm 0.81^{\mathrm{d}}$ \\
Behrng RID & $8.65 \pm 190^{\mathrm{c}}$ & Present system & \\
\hline
\end{tabular}

a HIgG values from Fisher SeraChem Control Serum data sheet (except Behring RID method).

b \pm 2 standard deviations

c Average of six determinations \pm 2 standard deviations.

d Average of five determinations \pm 2 standard deviations

assay was between 5 and $400 \mathrm{ng} \mathrm{ml}^{-1}$. The enhanced sensitivity of the HIgG assay over that obtained for $\alpha_{1}$-acid glycoprotein may be due to a higher affinity constant for the polyclonal antibody preparation used in this instance.

The HIgG assay system was further evaluated by determining $\mathrm{HIgG}$ in a control serum sample and comparing the results with those of other commercial methods. As shown in Table 1, results obtained for HIgG by the present method were in good agreement with those obtained by the other methods. Although the standard deviation $(0.41 \mathrm{~g}$ $1^{-1} ; n=5$ ) obtained here cannot be compared quantitatively with other methods because of different number of measurements $(n)$, the proposed FIA assay appears to yield a better precision. Recovery studies were also performed by spiking the control serum with three different amounts of HIgG. As can be seen in Table 2, the amounts of HIgG added were recovered with satisfactory accuracy.

In conclusion, a rapid, reproducible and accurate flow-injection sandwich enzyme-linked immunoassay system for proteins has been devel-

\section{TABLE 2}

Analytical recovery of standard HIgG additions to control serum

\begin{tabular}{lll}
\hline Added $\left(\mathrm{g} \mathrm{l}^{-1}\right)$ & Recovered $\left(\mathrm{g} \mathrm{l}^{-1}\right)^{\mathrm{a}}$ & Recovery (\%) \\
\hline 0.00 & $9.52 \pm 0.41$ & - \\
200 & $1156 \pm 0.42$ & 102 \\
4.00 & $13.69 \pm 0.45$ & 104 \\
800 & $1811 \pm 0.49$ & 107 \\
\hline
\end{tabular}

Average of three determinations \pm standard deviation, on the same sample oped. Compared with the flow-injection system proposed by de Alwis and Wilson [5] (30-min cycle time to gain adequate precision and accuracy), the present system increases the sample throughput rate (12-min cycle time) while maintaining comparable sensitivity and precision. It should be noted that the sensitivity of the method would probably be further improved if monoclonal antibodies toward two different sites on the analyte proteins were used in place of the polyclonal preparations. The immunoreactors can be used for several hundred assays (e.g., 300) without a significant decrease in antigen binding. As the injection and valve switching could be fully automated in the future, we believe that this type of flow-injection enzyme immunoassay system will provide an attractive alternative to conventional ELISA methods, particularly when rapid quantitative results are desired.

This work was partially supported by grants from the National Science Foundation (CHE8506695 and CHE-8813952) and Mallinckrodt Sensor Systems.

\section{REFERENCES}

1 E.T. Maggı (Ed.), Enzyme-Immunoassay, CRC, Boca Raton, FL, 1980.

2 M. Oellerich, J. Clın. Chem., Clın. Biochem., 18 (1980) 197.

3 D. Monroe, Anal. Chem., 56 (1984) 920A

4 A. Voller and D E. Bidwell, in W.P. Collins (Ed.), Alternative Immunoassay, Wiley, New York, 1985, p. 77.

5 W.U. de Alwis and G.S. Wilson, Anal. Chem., 57 (1985) 2754. 
6 W U de Alw1s and G S Wilson, Anal Chem, 59 (1987) 2789

7 Y M Fratıcellı and M E Meyerhoff, Anal Chem, 53 (1981) 992

8 M E Collison and M E Meyerhoff, Anal Chim. Acta, 200 (1987) 61

9 I H Lee and M E Meyerhoff, Mıkrochımica Acta, Part III, (1988) 207

$10 \mathrm{~J}$ L Palmer and A Nisonoff, Biochemistry, 3 (1964) 863

11 W J Mandy, M.M River and A Nisonoff, J Biol Chem, 236 (1961) 3221

12 W J Mandy and A Nisonoff, J Biol Chem, 238 (1963) 206

13 G S Bethell, J S Ayers, W S. Hancock and M T.W Hearn, J Biol Chem, 254 (1979) 2572
14 M T W. Hearn, G.S Bethell, J S. Ayers and W S. Hancock, J Chromatogr, 185 (1979) 463

15 D M Boorsma and G.L. Kalsbeek, J. Histochem Cytochem, 23 (1975) 200.

$16 \mathrm{~J}$ Keesey (Ed), Biochemical Information, Boehringer Mannheim Biochemicals, Indianapolis, IN, 1987, p 5

17 L.A Cantarero, J.E Butler and J W. Osborne, Anal. B1ochem, 105 (1980) 375.

18 J.E Hermann, R.M. Hendry and MF Collıns, J Clın. Microbiol, 10 (1979) 210

19 M T W. Hearn, E.L Harns, G.S Bethell, W.S. Hancock and J.S Ayers, J Chromatogr, 218 (1981) 509

20 G S Bethell, J S. Ayers, M T W Hearn and W S Hancock, J Chromalogr , 219 (1981) 361 